\title{
Scientific production in oncological palliative care with emphasis in communication
}

\author{
(iD) Fernando André Costa de Souza' \\ (iD) Alfredo Borreli \\ (iD) Maria Andréa Fernandes ${ }^{3}$ \\ Dolange Fátima Geraldo da Costa ${ }^{4}$ \\ (iD) Cristiani Garrido Andrade ${ }^{5}$ \\ (iD) Fernanda Ferreira de Andrade
}

\begin{abstract}
1. Médico. Residente em oncologia no Hospital do amor, Barretos, SP, Brasil. 2. Médico. Chefe do Serviço de Oncologia Hospital do Servidor Público Municipal de São Paulo, São Paulo, SP, Brasil. 3. Enfermeira. Membro do Núcleo de Estudo e Pesquisa em Bioética e Cuidados Paliativos. Doutoranda do Programa de Pós-graduação de Enfermagem da Universidade Federal da Paraíba, João Pessoa, PB, Brasil.

4. Enfermeira. Membro do Núcleo de Estudo e Pesquisa em Bioética e Cuidados Paliativos. Docente do Programa de Pós-graduação de Enfermagem da Universidade Federal da Paraíba, João Pessoa, PB, Brasil. 5. Enfermeira. Membro do Núcleo de Estudo e Pesquisa em Bioética e Cuidados Paliativos. Doutoranda do Programa de Pós-graduação de Enfermagem da Universidade Federal da Paraíba, João Pessoa, PB, Brasil. 6. Acadêmica de Medicina. Membro do Núcleo de Estudo e Pesquisa em Bioética e Cuidados Paliativos da Universidade Federal da Paraíba, João Pessoa, PB, Brasil.
\end{abstract}

http://dx.doi.org/10.1590/1806-9282.66.10.1455

\section{SUMMARY}

Communication is a facilitating tool in palliative care, enabling the development of a therapeutic process based on universal humanistic values, with benefits for the team, cancer patient, and family. This theme is of great importance and highlights the significant contributions to clinical practice in the context of palliative care in oncology with an emphasis on communication.

KEYWORDS: Palliative Care. Medical Oncology. Communication. Review.

\section{INTRODUCTION}

Communication is a fundamental therapeutic modality that goes far beyond words and content, contemplating also non-verbal signs and expressed by attentive listening, eye contact, and professional posture'. Communication improves the bond between the patient-team-family triad. In addition, it allows patients to express their decisions and maintain social contact, thus their wishes can be met up to the end of their lives'.
Considering the importance of palliative care in oncology with an emphasis on communication for healthcare academia, as well as for the medical practice, it is particularly important to develop studies that seek to highlight the scientific production on this subject. Faced with this context, this research aims to: Analyze the scientific production on palliative care in oncology, with an emphasis on communication and contributions to clinical practice. 


\section{METHODS}

This is an Integrative Literature Review that aims to summarize publications systematically and rigorously, allowing to characterize and disseminate the knowledge produced. This review aimed to answer the following question: what was the scientific production on palliative care in oncology with an emphasis on communication for clinical practice between 2010 and 2017? Works published as scientific articles in the languages: Portuguese, English, and Spanish.

The selection of papers was carried out based on searches in the following databases: Literatura Latino Americana e do Caribe em Ciências da Saúde (LILACS) and Public/Publish Medline (PubMed), upon searching the Biblioteca Virtual em Saúde (BVS) of the Latin American and Caribbean Center on Health Sciences Information (BIREME). We used the following descriptors of the Database, Cinahl Headings (MeSH), and of the Health Sciences Descriptors (DeCS), all of which were associated with the boolean operator "AND". "Palliative care" "oncology" "communication" "cuidados paliativos" "oncologia" "comunicação". Thus, considering all the publications identified in previously mentioned databases, 22 publications met our criteria.

Once the study sample was identified, to facilitate the process of organization for the collection of information relevant to the objectives of the present study, we used a form previously prepared by the researchers which allowed obtaining information on the characterization of the studies, approaches to the theme investigated, and contributions for clinical practice.

\section{RESULTS}

The study sample was comprised of 22 papers on palliative care in oncology and communication. Most publications were from 2017, i.e., 18.18\%. Regarding the databases, most studies were found on LILACS, with a percentage of $72.9 \%$. With respect to journals, important health magazines were the most prominent, most in the medical area, among which the following deserve to be highlighted: Journal of Palliative Medicine, Palliative Support Care, European Journal of Cancer Care, and the Journal of Clinical Oncology,

TABLE 1. DISTRIBUTION OF THE STUDIES PUBLISHED BY TITLE, OBJECTIVES, AND CONCLUSION REGARDING CATEGORY I - PALLIATIVE CARE IN ONCOLOGY: STUDIES ON COMMUNICATION MODALITIES. N=22

\begin{tabular}{|c|c|c|}
\hline Title & Objectives & Conclusion \\
\hline $\begin{array}{l}\text { Communicating bad news: } \\
\text { an Integrative Review of the } \\
\text { nursing literature }\end{array}$ & $\begin{array}{l}\text { Describe the process of communicating bad news and } \\
\text { identify how nurses communicate bad news. }\end{array}$ & $\begin{array}{l}\text { Nurses' approach and ability to transmit messages } \\
\text { influence the reaction of patients to information. }\end{array}$ \\
\hline $\begin{array}{l}\text { Comunicação interpessoal } \\
\text { com pacientes oncológicos em } \\
\text { cuidados paliativos }\end{array}$ & $\begin{array}{l}\text { Understand the process of interpersonal communi- } \\
\text { cation in patients' course of palliative care based on } \\
\text { Peplau. }\end{array}$ & $\begin{array}{l}\text { The needs felt by patients were met through effec- } \\
\text { tive communication. }\end{array}$ \\
\hline $\begin{array}{l}\text { A comunicação na transição } \\
\text { para os cuidados paliativos: } \\
\text { artigo de Revisão }\end{array}$ & $\begin{array}{l}\text { Present a brief Review of the national and internation- } \\
\text { al literature on communication during the transition } \\
\text { from curative care to palliative care in oncology }\end{array}$ & $\begin{array}{l}\text { The main focus of the published studies was to } \\
\text { prepare professionals for better communication } \\
\text { and interpersonal relationships, promote greater } \\
\text { safety and perception of their self-efficacy regard- } \\
\text { ing patients, family members, and members of } \\
\text { multidisciplinary teams. }\end{array}$ \\
\hline $\begin{array}{l}\text { Comunicação terapêutica na } \\
\text { Enfermagem: dificuldades para } \\
\text { o cuidar de idosos com câncer }\end{array}$ & $\begin{array}{l}\text { Assess the difficulties and their causes, from the nurs- } \\
\text { es' perspective, in providing assistance to the elderly } \\
\text { with oncologic pathologies. }\end{array}$ & $\begin{array}{l}\text { Nurses showed positive feelings, acknowledging } \\
\text { the importance of developing skills, such as ther- } \\
\text { apeutic communication, that can help patients to } \\
\text { have quality in palliative care. }\end{array}$ \\
\hline Compassionate Honesty & Report on communication in palliative care & $\begin{array}{l}\text { Honest communication of the clinical reality allows } \\
\text { patients to make better-informed decisions about } \\
\text { treatment options. }\end{array}$ \\
\hline Comunicação de Más Notícias & $\begin{array}{l}\text { Present suggestions for action on the verbal and } \\
\text { non-verbal dimensions of interpersonal communica- } \\
\text { tion that allow reducing patient, family, and profes- } \\
\text { sional stress and anxiety. }\end{array}$ & $\begin{array}{l}\text { People need to know the truth throughout their } \\
\text { lives, not only in the end, out of respect, so they } \\
\text { can develop autonomy and free-will. }\end{array}$ \\
\hline $\begin{array}{l}\text { Morte: o difícil desfecho a ser } \\
\text { comunicado pelos médicos }\end{array}$ & $\begin{array}{l}\text { Understand, from a physicians' perspective, the pro- } \\
\text { cess of communicating bad news. }\end{array}$ & $\begin{array}{l}\text { Considering the massive denial around death and } \\
\text { its interdiction, it is easy to understand how diffi- } \\
\text { cult it is to demand a dying patient to look at death } \\
\text { and to communicate it to their loved ones. }\end{array}$ \\
\hline $\begin{array}{l}\text { Comunicação de más notícias } \\
\text { pelos médicos no primeiro } \\
\text { ano de internato: um estudo } \\
\text { exploratório }\end{array}$ & $\begin{array}{l}\text { Explore the perspective of new interns regarding their } \\
\text { preparation to communicate bad news and regarding } \\
\text { the characteristics of medical programs curricula con- } \\
\text { sidered desirable for an adequate formation }\end{array}$ & $\begin{array}{l}\text { To improve the preparation of new interns in com- } \\
\text { municating bad news the emotional aspects of the } \\
\text { process must be approached. }\end{array}$ \\
\hline
\end{tabular}


which approach topics on palliative care practice and oncology. Most researchers on the subject were doctors (58\%), followed by the nurses.

Regarding the approach adopted in the studies of the sample, qualitative research was the most frequently used (50\%). The studies were conducted, in most cases (45\%), in hospitals. All of the keywords used in the studies were indexed in the DeCs (Descritores em Ciências da Saúde) and/or the Medical Subject Headings (MeSH).

The analysis of the studies allowed us to divide them into thematic categories, namely: communication modalities were emphasized in $36 \%$ of the studies; $40 \%$ were on communication instruments and strategies; and the communication between patients and family caregivers was the focus of $24 \%$ of the publications, as presented in Tables 1, 2, and 3.

\section{DISCUSSION}

Based on the analysis of information, the studies were grouped into categories to better understand and analyze the discussion, as shown in Tables 1, 2, and 3. With the purpose of summarizing the findings, we will present a brief discussion of each category listed below.

Regarding the communication modalities (Table 1), the methods for transmitting a message using both verbal and non-verbal communication, and the effectiveness in using them when communicating bad news is a significant ability in clinical practice that should be optimized by professionals in the palliative team.

The communication of bad news causes impacts, but there are meager findings in the literature regarding the performance of nurses in this respect, particularly in publications that relate to chronic, progressive,

TABLE 2. DISTRIBUTION OF THE STUDIES PUBLISHED BY TITLE, OBIECTIVES, AND CONCLUSION REGARDING CATEGORY II - PALLIATIVE CARE IN ONCOLOGY: STUDIES ON COMMUNICATION STRATEGIES AND INSTRUMENTS. $\mathrm{N}=22$

\begin{tabular}{|c|c|c|}
\hline Title & Objectives & Conclusion \\
\hline $\begin{array}{l}\text { Assessment of cancer pain in a patient } \\
\text { with communication difficulties: a case } \\
\text { report }\end{array}$ & $\begin{array}{l}\text { Use the Abbey Pain Scale to assess cancer pain } \\
\text { in patients with communication difficulties }\end{array}$ & $\begin{array}{l}\text { The use of the Abbey Pain Scale assists in the } \\
\text { approach to relieve the pain of non-communi- } \\
\text { cative patients with cancer. }\end{array}$ \\
\hline $\begin{array}{l}\text { Does communication skills training make } \\
\text { a difference in patients' experiences of } \\
\text { consultations in oncology and palliative } \\
\text { care services? }\end{array}$ & $\begin{array}{l}\text { Assess whether advanced training in communi- } \\
\text { cation skills enhances the experience of patient } \\
\text { consultations. }\end{array}$ & $\begin{array}{l}\text { Training in communication skills reflects } \\
\text { greater professional empathy as assessed by } \\
\text { patients and enhances the experience during } \\
\text { consultations }\end{array}$ \\
\hline $\begin{array}{l}\text { Association between patient-reported } \\
\text { symptoms and nurses' clinical impres- } \\
\text { sions in cancer patients admitted to an } \\
\text { acute palliative care unit }\end{array}$ & $\begin{array}{l}\text { Prospectively compare symptoms reported by } \\
\text { patients using the Edmonton Symptom Assess- } \\
\text { ment System instrument. }\end{array}$ & $\begin{array}{l}\text { The clinical perspective of nurses highly } \\
\text { trained in palliative care showed a weak } \\
\text { association with the intensity of symptoms } \\
\text { reported by the patient. }\end{array}$ \\
\hline $\begin{array}{l}\text { Specific training program improves oncol- } \\
\text { ogists' palliative care communication skills } \\
\text { in a randomized controlled trial. }\end{array}$ & $\begin{array}{l}\text { Demonstrate that concise and individual training } \\
\text { in communication skills improves the commu- } \\
\text { nication skills of oncologists in consultations } \\
\text { focused on the transition to palliative care. }\end{array}$ & $\begin{array}{l}\text { Concise and individual training in commu- } \\
\text { nication skills improved specific and general } \\
\text { communication skills of quite inexperienced } \\
\text { physicians. }\end{array}$ \\
\hline $\begin{array}{l}\text { Pediatric Palliative Care in the Age of } \\
\text { eHealth: Opportunities for Advances } \\
\text { in HIT to Improve Patient-Centered Com- } \\
\text { munication }\end{array}$ & $\begin{array}{l}\text { Seeks to identify the effective use of existing and } \\
\text { under-development information technology in } \\
\text { healthcare to improve communication and care } \\
\text { in a clinical setting. }\end{array}$ & $\begin{array}{l}\text { Provides a model for more optimized use of } \\
\text { technologies, effectively using technology } \\
\text { solutions based on standards to improve com- } \\
\text { munication and the quality of care. }\end{array}$ \\
\hline $\begin{array}{l}\text { Discussing the transition to palliative care: } \\
\text { evaluation of a brief communication skills } \\
\text { training program for oncology clinicians. }\end{array}$ & $\begin{array}{l}\text { Develop a brief communication skills workshop } \\
\text { to assist oncologist during the transition from } \\
\text { active anti-cancer treatment to palliative care }\end{array}$ & $\begin{array}{l}\text { The workshop provided relevant practical } \\
\text { information to participants and increased } \\
\text { confidence in the communication about the } \\
\text { transition to palliative care. }\end{array}$ \\
\hline $\begin{array}{l}\text { Addressing the transition from curative to } \\
\text { palliative care: concept and acceptance of } \\
\text { specific communication skills training for } \\
\text { physicians in oncology COM-ON- }\end{array}$ & $\begin{array}{l}\text { Evaluate a concise and individual training ses- } \\
\text { sion on communication skills }\end{array}$ & $\begin{array}{l}\text { The specific, individual, and concise training } \\
\text { session on communication skills presented } \\
\text { is well accepted, and physicians found there } \\
\text { were a high practical relevance and strong } \\
\text { personal benefits. }\end{array}$ \\
\hline $\begin{array}{l}\text { Caracterização dos recursos de comuni- } \\
\text { cação utilizados por pacientes em cuida- } \\
\text { dos paliativos - Revisão integrativa }\end{array}$ & $\begin{array}{l}\text { Complete an integrative review of publications } \\
\text { regarding the role of speech therapists on com- } \\
\text { munication strategies in palliative care }\end{array}$ & $\begin{array}{l}\text { Different forms of non-verbal communica- } \\
\text { tion are the most frequently used resource, } \\
\text { and communication is an important factor } \\
\text { for maintaining dignity and comfort in this } \\
\text { scenario. }\end{array}$ \\
\hline $\begin{array}{l}\text { The P-A-C-I-E-N-T-E Protocol: An in- } \\
\text { strument for breaking bad news adapted } \\
\text { to the Brazilian medical reality }\end{array}$ & $\begin{array}{l}\text { Proposes a genuinely Brazilian communication } \\
\text { tool and assesses its acceptance among physi- } \\
\text { cians and nurses }\end{array}$ & $\begin{array}{l}\text { The PACIENTE Protocol was proposed as a } \\
\text { tool to guide and facilitate communication } \\
\text { and proved to be practical and useful for most } \\
\text { participants of this study. }\end{array}$ \\
\hline
\end{tabular}


TABLE 3. DISTRIBUTION OF THE STUDIES PUBLISHED BY TITLE, OBJECTIVES, AND CONCLUSION REGARDING CATEGORY III - PALLIATIVE CARE IN ONCOLOGY COMMUNICATION: STUDIES ON PATIENTS AND FAMILY CAREGIVERS. $\mathrm{N}=22$

\begin{tabular}{|c|c|c|}
\hline Title & Objectives & Conclusion \\
\hline $\begin{array}{l}\text { De um lado ao outro: o que é essencial? } \\
\text { Percepção dos pacientes oncológi- } \\
\text { cos e de seus cuidadores ao iniciar o } \\
\text { tratamento oncológico e em cuidados } \\
\text { paliativos }\end{array}$ & $\begin{array}{l}\text { Assess the perception of oncology } \\
\text { patients and their caregivers at the be- } \\
\text { ginning of the diagnostic and therapeutic } \\
\text { approach, and during palliative care. }\end{array}$ & $\begin{array}{l}\text { Trust mediated by good communication and constan- } \\
\text { cy of care are seen as fundamental for the satisfaction } \\
\text { of caregivers and cancer patients throughout the } \\
\text { course of the disease. }\end{array}$ \\
\hline $\begin{array}{l}\text { Importância da comunicação nos cuida- } \\
\text { dos paliativos em oncologia } \\
\text { pediátrica: enfoque na Teoria Hu- } \\
\text { manística de Enfermagem }\end{array}$ & $\begin{array}{l}\text { Investigate and analyze communication } \\
\text { in palliative care in pediatric oncology, } \\
\text { from the perspective of nurses, based on } \\
\text { the Humanistic Theory of Nursing. }\end{array}$ & $\begin{array}{l}\text { Communication is considered an effective element in } \\
\text { the care of children with cancer and is of the utmost } \\
\text { importance to promote palliative care when grounded } \\
\text { in the Humanistic Theory of Nursing. }\end{array}$ \\
\hline Cuidados paliativos à criança com câncer & $\begin{array}{l}\text { Understand the existential experience } \\
\text { of nurses when caring for children with } \\
\text { cancer without therapeutic possibilities. }\end{array}$ & $\begin{array}{l}\text { Nurses acknowledge the importance of communica- } \\
\text { tion with children with cancer } \\
\text { undergoing palliative care. There was an emphasis } \\
\text { on attention to the non-verbal behavior of children, } \\
\text { through eye contact and touch. }\end{array}$ \\
\hline $\begin{array}{l}\text { Cuidados paliativos sob a ótica de } \\
\text { familiares de pacientes com neoplasia } \\
\text { de pulmão }\end{array}$ & $\begin{array}{l}\text { Learn what family members of patients } \\
\text { with lung cancer understand of this } \\
\text { therapy }\end{array}$ & $\begin{array}{l}\text { The research indicates the need for training on and dif- } \\
\text { fusion of palliative care practices, particularly regarding } \\
\text { communication as a tool for improving care. }\end{array}$ \\
\hline $\begin{array}{l}\text { Crianças e adolescentes com câncer } \\
\text { em cuidados paliativos: experiência de } \\
\text { familiares }\end{array}$ & $\begin{array}{l}\text { Investigate the experience of family } \\
\text { members when caring for children and } \\
\text { adolescents with cancer, undergoing } \\
\text { palliative care, particularly in end-of-life } \\
\text { care. }\end{array}$ & $\begin{array}{l}\text { Family knowledge and participation in end-of-life care } \\
\text { are driven by the communication of difficult updates } \\
\text { between health teams, patients, and their families. } \\
\text { However, this communication, when present, proved } \\
\text { to be ineffective, with confusing and ambiguous } \\
\text { information. }\end{array}$ \\
\hline
\end{tabular}

and potentially fatal diseases ${ }^{2}$. The communication of bad news may involve not only the disclosure of the diagnosis, but also the disease progression, and the need for referral to palliative care and home care. Communication is understood as a means for achieving and maintaining a more solid and healthy relationship between the health team, patient, and family members. Through effective communication, the team was able to mobilize the best capabilities and potentials of human beings to face stressful situations and preserve the autonomy and dignity of individuals under their care c.4. $^{3.4}$

Findings show that the difficulties and causes experienced by nurses in this context of care require emotional control in order to have therapeutic communication between professionals and patients ${ }^{5}$.

Research shows that communication should be understood as a resource that aims at creating environments that ensure patients' needs are met satisfactorily by sharing their experiences, anxieties, and insecurities. Thus, care should be focused on the need to communicate as a therapeutic strategy in order to connect the caregiver to the patient ${ }^{6}$. Thus, telling the truth is imperative in this context of care, since the learning of how to prevent a lack of sensitivity requires not only good intentions but strong communication skills?.

The study is about the communication of difficult news and brings suggestions for verbal and non-verbal interpersonal communication that aim to minimize the emotional suffering of patients, family members, and professionals, and the difficulties of physicians in the process of communicating bad news, in particular of recently graduated physicians ${ }^{8.9}$.

When it comes to communicating difficult news, it is usual for physicians to use phrases in the first person: "I represented a huge hope and, at that moment, I felt like a failure." This feeling of failure is a barrier for physicians when communicating difficult news to family members since physicians themselves see death as a failure ${ }^{10}$. Research highlights that communication or lack thereof between physicians and patients is a constant problem ${ }^{11}$. This problem is a likely reflection of medical training, which is seen as a healing practice, causing many professionals to act mechanically in their daily practices and making them feel powerless in the face of terminality and death.

Non-verbal communication is about decoding relevant emotional information based on the various non-verbal signs, such as facial expressions, body gestures, among others ${ }^{12.13}$. It is important for professionals to understand that the body speaks through words and signs. Communicational interaction should occur in an informative, sensitive, and possible manner to support patients and their family members in understanding and overcoming the difficulties and limiting situations that the disease imposes.

Research in the category of communication 
instruments and strategies in oncology (Table 2) focused on the assessment of cancer pain in a patient with communication difficulties using the Abbey Pain Scale, which includes six items to assess pain, including vocal verbal and non-verbal complaints ${ }^{14}$. Another study used the protocol for Consultation Measurement and Relational Empathy, which is a brief questionnaire designed to assess the perceptions of patients on relational empathy during consultations $^{15}$. The research addressed the use of the Edmonton scale for the assessment of symptoms, a self-reporting tool that allows patients with advanced cancer to document the intensity of nine common symptoms ${ }^{16}$.

Studies provided a training program with the objective of improving the communication behavior of doctors towards patients with cancer during the transition from curative or oncologic treatment to palliative care. The research used the COM-ON Checklist, which consists of specific items for the transition to palliative care, general communication skills, physicians' skills for handling the emotional needs of patients, and other significant ones ${ }^{17.18}$. The study developed a brief communication skills workshop to assist oncology health professionals during the transition from active anti-cancer treatment to palliative care ${ }^{19}$.

In this context, it is necessary to highlight the potential of health information technology (HIT) ${ }^{20}$. E-Health technologies can improve the quality of care provided, reduce medical errors, and allow efficient communication to support joint decision-making. Findings indicate the importance of speech therapists, who allow the maintenance of oral communication as much as possible and work in the transition to alternative communication, protecting patients' right to express themselves, without interruption of the possibility to communicate ${ }^{21}$. Another study used the PACIENTE protocol and found that the worst task to be performed during communication is "talking about death," followed by "discussing the end of attempts to curative treatment," and the "diagnosis" in itself22.

The studies are unanimous in stating that more research is needed to identify the tools that are suitable for making these assessments in the context of different symptoms and settings and to develop the necessary training by health care providers to integrate these tools and the information they produce into clinical practice.

The category of studies on palliative care with an emphasis on communication carried out with patients and family caregivers (Table 3), found that the most important subsidies for patients, at the start of their treatment, are: the availability of physicians to discuss the disease and answer their questions, trust in the team, and accessible and understandable communication ${ }^{23}$. Studies emphasize that it is essential that nurses, in their practice, identify the needs of children with cancer through verbal communication, characterized as the dialogic aspect of Nursing, and non-verbal communication, in which the child is perceived as a unique being in the relationships of care $^{24.25}$.

So the communication between team/family is essential in the construction of care for patients with cancer since the absence of communicative action could compromise the fight against the disease ${ }^{26}$. On the other hand, a study conducted with family members of children and adolescents with cancer noted a feeling of helplessness in the care of children, adolescents, and family members when the expression "there is nothing else we can do" is verbalized, confirming that the clarity, knowledge, and objectivity with which information is passed on to family members are, in general, ambiguous, inaccurate, and often lacking in comparison to the philosophy of palliative care $^{27}$.

Findings point to a lack of knowledge by family members when a child and or adolescent with cancer begins palliative care ${ }^{28}$. In these situations, the family notices the team's lack of interest in the continuation of treatment, thus losing trust in information and conducts $^{29}$. Therefore, trust mediated by good communication and constancy of care are seen as fundamental for the satisfaction of caregivers and cancer patients throughout the course of the disease. Thus, in palliative care, assistance to patients with cancer and their families should be more human and holistic, based on strategies such as communication, which can develop a therapeutic process based on universal humanistic values with benefits for all.

\section{CONCLUSION}

The present study contributes significantly to clinical practice in the context of palliative care in oncology, with an emphasis on communication. However, considering the reduced number of publications on the subject over a period of eight years, future studies are recommended to subsidize the expansion of knowledge in the area. 


\section{Author's Contribution}

Fernando André Costa de Souza worked in the drafting of the paper; Alfredo Borreli, Maria Andréa Fernandes, and Solange Fátima Geraldo da Costa worked in the critical review and approval of the

version to be published; Cristiani Garrido Andrade and Fernanda Ferreira de Andrade worked on the data analysis and interpretation, and on the drafting of the paper.

\section{RESUMO}

A comunicação é uma ferramenta facilitadora nos cuidados paliativos, possibilitando o desenvolvimento de um processo terapêutico baseado em valores humanísticos universais, com benefícios para equipe, paciente oncológico e família. Essa temática é de grande importância e evidencia as contribuições significativas para a prática clínica no contexto dos cuidados paliativos em oncologia com ênfase na comunicação.

PalaVRas-Chave: Cuidados Paliativos. Oncologia. Comunicação. Revisão.

\section{REFERENCES}

1. Nogueira JWS, Rodrigues MCS. Comunicação efetiva no trabalho em equipe em saúde: desafio para a segurança do paciente. Cogitare Enferm. 2015;20(3):636-40.

2. Fontes $C M B$, Menezes DV, Borgato MH, Luiz MR. Comunicação de más notícias: revisão integrativa de literatura na enfermagem. Rev Bras Enferm. 2017;70(5):1089-95.

3. Borges MM, Santos Junior R. A comunicação na transição para os cuidados paliativos: artigo de revisão. Rev Bras Educ Méd. 2014;38(2):275-82.

4. Galvão MIZ, Borges MS, Pinho DLM. Interpersonal communication with oncological patients in palliative care. Rev Baiana Enferm. 2017;31(3):e22290.

5. Peterson AA, Carvalho EC. Comunicação terapêutica na enfermagem: dificuldades para o cuidar de idosos com câncer. Rev Bras Enferm. 2011;64(4):692-7.

6. Campos CM. A comunicação terapêutica enquanto ferramenta profissional nos cuidados de enfermagem. Psilogos. 2017;15(1):91-101.

7. Loprinzi CL, Schapira L, Moynihan T, Kalemkerian GP, von Gunten C, Steensma D. Compassionate honesty. J Palliat Med. 2010;13(10):1187-91.

8. Silva MJP. Comunicação de más notícias. O Mundo da Saúde. 2012;36(1):49-53.

9. Leal-Seabra F, Costa MJ. Comunicação de más notícias pelos médicos no primeiro ano de internato: um estudo exploratório. Rev Fund Educ Méd. 2015;18(6):387-95

10. Monteiro DT, Reis CGC, Quintana AM, Mendes IMR. Morte: o difícil desfecho a ser comunicado pelos médicos. Estud Pesqui Psicol. 2015;15(2):547-67.

11. Miranda ACA, Feliciano KVO, Sampaio MA. A comunicação médico-paciente na percepção de mulheres com nódulo mamário e indicação de biópsia. Rev Bras Saúde Mater Infant. 2014;14(3):251-60.

12. Elliott AM, Alexander SC, Mescher CA, Mohan D, Barnato AE. Differences in physicians' verbal and nonverbal communication with black and white patients at the end of life. J Pain Symptom Manage. 2016;51(1):1-8.

13. Zhou Y, Fischer MH.Mimicking non-verbal emotional expressions and empathy development in simulated consultations: an experimental feasibility study. Patient Educ Couns. 2018;101(2):304-9.

14. Okimasa S, Saito Y, Okuda H, Fukuda T, Yano M, Okamoto Y, et al. Assessment of cancer pain in a patient with communication difficulties: a case report. J Med Case Rep. 2016;10(3):148.

15. Johnson LA, Gorman C, Morse R, Firth M, Rushbrooke S. Does communication skills training make a difference to patients' experiences of consultations in oncology and palliative care services? Eur Cancer Care. 2013;22(2):202-9.

16. Rhondali W, Hui D, Kim SH, Kilgore K, Kang JH, Nguyen L, et al. Association between patient-reported symptoms and nurses' clinical impressions in cancer patients admitted to an acute palliative care unit. I Palliat Med. 2012;15(3):301-7.
17. Goelz T, Wuensch A, Stubenrauch S, Ihorst G, Figueiredo M, Bertz H, et al. Specific training program improves oncologists' palliative care communication skills in a randomized controlled trial. | Clin Oncol. 2011;29(25):3402-7.

18. Goelz T, Wuensch A, Stubenrauch $S$, Bertz H, Wirsching M, Fritzsche $K$. Addressing the transition from curative to palliative care: concept and acceptance of a specific communication skills training for physicians in oncology-COM-ON-p. Onkologie. 2010;33(1-2):65-9.

19. Grainger MN, Hegarty $S$, Schofield $P$, White $V$, lefford M. Discussing the transition to palliative care: evaluation of a brief communication skills training program for oncology clinicians. Palliat Support Care. 2010;8(2):441-7.

20. Madhavan S, Sanders AE, Chou WY, Shuster A, Boone KW, Dente MA, et al. Pediatric palliative care and eHealth opportunities for patient-centered care. Am J Prev Med. 2011;40(5 Suppl 2):S208-16.

21. Silva CLM, Bertoncelo $C$, Barros APB, Padovani M. Caracterização dos recursos de comunicação utilizados por pacientes em cuidados paliativos: revisão integrativa. Rev CEFAC. 2017;19(6):879-88.

22. Pereira CR, Calônego MAM, Lemonica L, Barros GAM. The $p-a-c-i-e-n-$ t-e protocol: an instrument for breaking bad news adapted to the Brazilian medical reality. Rev Assoc Med Bras. 2017;63(1):43-9.

23. Munhoz BA, Paiva HS, Abdalla BMZ, Zaremba G, Rodrigues AMP, Carretti $M R$, et al. De um lado ao outro: o que é essencial? Percepção dos pacientes oncológicos e de seus cuidadores ao iniciar o tratamento oncológico e em cuidados paliativos. Einstein. 2014;12(4):485-91.

24. França JRFS, Costa SFG, Lopes MEL, Nóbrega MML, França ISX. Importância da comunicação nos cuidados paliativos em oncologia pediátrica: enfoque na teoria humanística de enfermagem. Rev Latino-Am Enferm. 2013;21(3):1-7.

25. França JRFS, Costa SFG, Nóbrega MML, Lopes MEL. Cuidados paliativos à criança com câncer. Rev Enferm UERJ. 2013;21(esp.2):779-84.

26. Furtado MEMF, Leite DMC. Cuidados paliativos sob a ótica de familiares de pacientes com neoplasia de pulmão. Interface. 2017;21(63):969-80.

27. Sanches MVP, Nascimento LC, Lima RAG. Crianças e adolescentes com câncer em cuidados paliativos: experiência de familiares. Rev Bras Enferm. 2014;67(1):28-35.

28. Misko MD, Santos MR, Ichikawa CRF, Lima RAG, Bousso RS. A experiência da família da criança e/ou adolescente em cuidados paliativos: flutuando entre a esperança e a desesperança em um mundo transformado pelas perdas. Rev Latino-Am Enferm. 2015;23(3):560-7.

29. Silva SED, Costa IL, Araújo IS, Moura AAA, Cunha NMF Cunha FF Os impactos da terapia quimioterápica e as implicações para a manutenção do cuidado. Um estudo de representações sociais. Rev Pesqui Cuid Fundam. 2018;10(2):516-23. 